> Tips om medisinsk litteratur, andre bøker, filmer og elektroniske medier som bør anmeldes, sendes tidsskriftet@legeforeningen.no

\section{Troverdig og sterkt om tap, sorg og mestring}

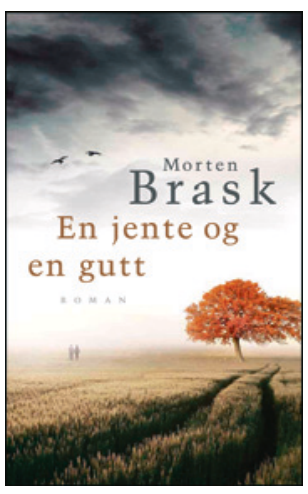

Morten Brask

En jente og en gutt

243 s. Oslo: Spartacus Forlag, 2014

Pris NOK 299

ISBN 978-82-430-0908-0

Dette er en fars fortelling om en dramatisk hendelse som skjedde for 14 år siden, men som for alltid vil ha en stor plass i hans liv. Med intens ærlighet og detaljrikdom forteller han om forelskelse, om den sterke, men vanskelige kjærligheten til Maja, og om hovedpersonene - deres små tvillinger, en jente og en gutt - om deres korte, intense, men viktige liv, og om den vanskelige tiden før og etter barnas fødsel og død.

Boken har fire deler, Øya, Byen, Sykehuset og Kirkegården. Øya er «det gode liv» med forelskelse og fremtidsdrømmer. Når beslutningen om å få barn er tatt, kommer nye utfordringer. Graviditet og svangerskap blir medisinsk, fremmedgjort og angstfylt, og avsluttes med en dramatisk fødsel av to meget for tidlig fødte barn. Dagene på sykehuset inneholder hele spektret av glede, sorg, håp og avmakt. Medisinske hendelser er detaljert beskrevet, likeså den vanskelige kommunikasjonen mellom foreldrene og personalet på avdelingen, og med venner og familie. Deretter følger den grenseløse fortvilelsen med foreldrenes forskjellige mestringsmåter og sorgreaksjoner, fremmedfølelsen for hverandre og til sist møtet ved barnas grav, med adskillelsen og erkjennelsen om at forholdet mellom dem er slutt, så veien videre - mot resten av livet. Han har beskrevet sin bunnløse sorg, savnet av barna, sorgen over det livet de ikke fikk leve sammen, men åpner også for muligheten om at gode dager kan komme.

Hvem er boken ment for? For forfatteren selv er dette bearbeidelse av egen sorg, men nok også et ønske om å nå andre med liknende opplevelser. Jeg tror mange vil ha utbytte av å lese den, men på forskjellige måter og av forskjellige grunner. Hendelsen ligger 14 år tilbake i tid, men er sterkt preget av detaljer, av hvem som sa hva når, beskrivelse av lyder, stemmer, omgivelser, stemninger, en lang prosess fra opplevelse til setninger er formulert. Dette bekrefter igjen at slike opplevelser tar stor plass i livet og varer veldig lenge.

Den engasjerende teksten er stram i språket. Helsepersonell som arbeider i nyfødtmedisin, vil kjenne seg igjen, både i den medisinske fremstillingen, men også i den utfordrende kommunikasjonen slike hendelser krever. Noe av den medisinske informasjonen som er gjengitt, er ikke alltid lett å forstå rent faglig. Det er kanskje enda en bekreftelse på hvor vanskelig det er å formidle faglig informasjon i en slik situasjon. For boken som helhet er det ikke viktig.

Jeg tror boken vil kunne føre til økt forståelse og klokskap hos venner og familie. Teksten er en bekreftelse på at sorgen over å miste barn ikke går over, men at den kan mestres og inkluderes i livet.

Inger Elisabeth Silberg

Overlege, Intensivpost for nyfødte

Kvinne- og barneklinikken

Oslo universitetssykehus, Rikshospitalet

\section{Nyttig om tvangslidelser hos barn og unge}

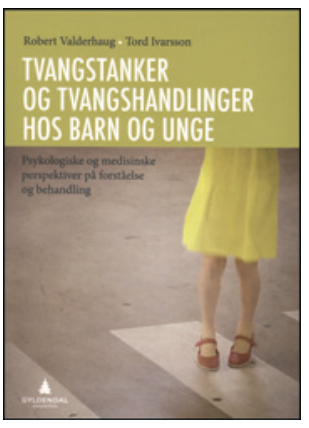

Robert Valderhaug, Tord Ivarsson

Tvangstanker og tvangshandlinger hos barn og unge

Psykologiske og medisinske perspektiver på forståelse og behandling. $240 \mathrm{~s}$, tab, ill. Oslo: Gyldendal Akademisk, 2014. Pris NOK 365 ISBN 978-82-05-45353-1

Målgruppen er fagfolk, men forfatterne håper at legfolk også kan ha nytte av boken. Robert Valderhaug er psykologspesialist og forsker tilknyttet Regionalt kunnskapssenter for barn og unge (RKBU) MidtNorge. Tord Ivarsson er barne- og ungdomspsykiater og forsker tilknyttet Regionsenter for barn og unges psykiske helse (RBUP) Øst-Sør. Begge har klinisk erfaring fra barne- og ungdomspsykiatrien, og begge deltar i et større nordisk forskningsprosjekt om barn og tvangslidelser.

Forfatterne begrunner utgivelsen med at de bøkene om barn og unge og tvang som er utgitt på norsk de siste tiårene, har vært behandlingsmanualer. De er skeptiske til at manualer blir klinikernes eneste faglige støtte. I boken viser de tydelig hvorfor en slik utvikling er uheldig. Minst $75 \%$ av barn og unge med tvang har komorbide tilstander, og tvangstilstander kan differensialdiagnostisk være vanskelig å skille fra bl.a. ulike angstlidelser, tics/Tourettes syndrom, høytfungerende autister og psykoser.

Tvangslidelser blir omtalt som psykiatriens kameleon. I tillegg er holdningene i omgivelsene til barnet viktig, særlig familiens. Foreldrene velger ofte å tilrettelegge i forhold til symptomene da dette sparer både barnet og familien for stress og frustrasjon. På lengre sikt vil dette imidlertid ofte være en vedlikeholdende faktor. Diagnostikk av tvangslidelser krever derfor grundig utredning, og behandlingen må rette seg både mot psykoedukasjon og familiearbeid, i tillegg til de mer spesifikke terapeutiske teknikkene, eventuelt med tillegg av medikamentell behandling.

Forfatterne tar i de første kapitlene opp epidemiologi, kliniske trekk og familie og samspill. Deretter følger et grundig kapittel om utredning og diagnostikk. De behandler så kunnskap og nyere teorier om hjerneorganiske prosesser som man mener har betydning for utviklingen av tvang. Til slutt tar de for seg behandling der evidensbasert kognitiv atferdsterapi (KAT) med eksponering og responsprevensjon (ERP) er integrert i et bredere perspektiv med oppbygging av behandlingsallianse, psykoedukasjon og familiearbeid. Når det gjelder konkret fremgangsmåte, henvises det til en behandlingsmanual (1) som nylig ble omtalt i Tidsskriftet (2). Det er godt belegg for at medikamentell behandling har effekt som andrelinjebehandling når kognitiv atferdsterapi alene ikke gir tilstrekkelig utbytte. Boken har også et nyttig kapittel om hvordan man skal tenke ved mangelfull behandlingsrespons.

Boken har mest relevans for fagfolk i spesialisthelsetjenesten. Den er lettlest og oversiktlig, og egner seg både som lærebok og som oppslagsbok på skrivebordet.

\footnotetext{
Marit Hafting

Barne- og ungdomspsykiater, BUP Voss

Voss sjukehus

Litteratur

1. Weidle B. red. OCD-behandling for barn og unge: En praksismanual. Oslo: Gyldendal Akademiske, 2014.

2. Sandbu M. Bruksbok mot tvang hos barn og unge. Tidsskr Nor Legeforen 2015; 135: 456.
} 